JOSING: Journal of Nursing and Health

Volume 1, Nomor 1, Desember 2020

e-ISSN: $2745-7877$

p-ISSN: 2746-0851

DOI: https://doi.org/10.31539/josing.v1i1.1165

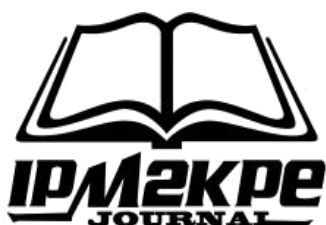

\title{
HYPNOBIRTHING PAIN MANAGEMENT FOR MATERNAL PAIN ADAPTATION ALONG LABOR PROCESS
}

\author{
Yessi Andriani ${ }^{1}$, Def Primal $^{2}$, Mera Delima $^{3}$ \\ Padang Pioneer College of Health Sciences ${ }^{1,2,3}$ \\ yessi.andriani16@gmail.com ${ }^{1}$
}

\begin{abstract}
The purpose of this study was to determine the effect of hypnobirthing pain management on the adaptability of maternal pain spontaneously. This study uses a quantitative approach to the design quasi-experimental design with treatment replications (pretest posttest with control group. Research results showed the existence difference in pain adaptation in mothers who are given hypnobirthing pain management intervention is 1,00 (able to adapt). No differences in pain adaptation in women who were not given pain management interventions hipnobirthing ie -0.62 (not able to adapt). Bivariate results revealed the influence of hypnobirthing pain management on the adaptation ability of maternal pain that gave birth spontaneously $(p=0.002)$. We conclude that there is an influence of hypnobirthing pain management on pain adaptability. It is expected that medical services are able to apply hypnobirthing pain management to maternity mothers, and expected to make standardized services procedures on hypnobirthing management for pain relaxations.
\end{abstract}

Keywords : Hypnobirthing, Pain Adaptation, Pain Management

\section{INTRODUCTION}

Maternal Mortality according to the World Health Organization (WHO) definition is death during pregnancy or in the 42 day period after the end of pregnancy. The ratio of maternal deaths in developing countries in 2015 was 239 per 100,000 live births, while in developed countries 12 per 100,000 live births in developed countries (WHO, 2015). One of the indicators of the health of Sustainable Development Goals (SDGs) in Indonesia is ensuring a healthy life and promoting prosperity for all people in 2030, among others by reducing the Maternal Mortality Rate (MMR) to below 70 per 100,000 live births (Ermalena, 2017). However, according to the 2012 Indonesian Basic Health Survey (IDHS) the number of MMR has only reached 359 maternal deaths per 100,000 live births. In 2015, the MMR showed a decrease to 305 maternal deaths per 100,000 live births based on the 2015 Intercensal Population Survey (SUPAS) (Kemenkes RI, 2017).

The contribution of pregnancy and childbirth in Indonesia is quite heavy, namely maternal mortality 390 / 100,000 births, and perinatal deaths around 400 / 100,000 live births. Estimates of childbirth occur as many as 5,000,000 people per year (Manuaba, 2014). During the birth process will be divided into 4 parts, namely stage 1, stage 2, stage 3 and stage 4 (Varney, 2012). The maternal mortality rate in West Sumatra (West Sumatra) in 2017 numbered 107 people, a decrease compared to 2015 (111 people). The details of maternal mortality consist of 30 maternal deaths, 25 maternal deaths and 52 
postpartum maternal deaths (West Sumatra Health Office, 2018). Over the past 2 years, at the Hospital dr. Achmad Mochtar Bukittinggi there was no maternal death. Data on vaginal delivery at Dr. dr. Achmad Mochtar in 2017 got 589 people, and in the period January - June 2018 there were 229 deliveries or an average of 38 people per month (Medical Record Bukittinggi Hospital, 2018).

Normal labor is a low-risk labor with spontaneous onset, the fetus is at the vertex presentation, and its peak, the condition of the mother and baby after birth is quite good. Normal delivery occurs between 37 and 42 weeks' gestation. The onset of labor is a process, so it is very difficult to determine exactly when a painless (or sometimes very painful) pre-labor contraction develops into a progressive and rhythmic labor contraction. The biological, psychological, social, spiritual, cultural and educational dimensions of each woman have an impact on how she expresses herself and how she feels pain during labor (Fraser, Cooper, 2012). Labor pain is a physiological condition, labor pain starts in labor in the first stage of the latent and active phases. The latent phase occurs opening up to $3 \mathrm{~cm}$, can last for 8 hours. Pain originates from uterine contractions and cervical dilatation, as the volume and frequency of uterine contractions increase, the pain will feel stronger, the peak of pain occurs in the active phase, where the opening occurs from $3 \mathrm{~cm}$ to $10 \mathrm{~cm}$ and lasts for 6 hours. Pain that occurs can affect the mother's condition in the form of fatigue, fear, worry and stress. Stress can cause a weakening of uterine contractions and end in prolonged labor and can even cause death (Sarwono, 2011).

The intensity of pain experienced by the mother will increase over time due to contractions, amplitude, frequency and duration which are increasingly increasing (Prawiroharjo, 2008). The increased intensity of pain results in extreme pain. Pain control can be done pharmacologically and non pharmacologically. Nonpharmacological pain control methods can be done through breathing and relaxation techniques, massage, hydrotherapy, aromatherapy, transcutaneous electric blood stimulation, reflexology, homeopathy, music therapy, acupuncture, and herbal medicine (Fraser, Cooper, 2012). This is in accordance with Wildan's research (2013), that relaxation techniques affect the adaptation of first-stage labor pain in the BPS Working Area Patrang Health Center in Jember Regency. The level of pain before relaxation of mild pain is $0 \%$, moderate pain $26.67 \%$, severe pain $73.33 \%$, whereas after relaxation techniques the pain becomes mild pain $36.67 \%$, moderate pain $60.00 \%$, severe pain $3.33 \%$.

One method to overcome the pain of non-pharmacological labor that has begun to be developed is the method of labor with hypnobirthing. Hypnobirthing is one of the non-pharmochological pain management, which includes deep relaxation, slow breathing patterns and instructions on how to release endorphins from the body. Hypnobirthing means the process of childbirth with hypnosis, the mother is fully aware and enjoys the process of childbirth. This method is rooted in the science of hypnosis with a psychiatric approach that gives women the opportunity to concentrate, focus, and relax, so hypnobirthing is more referring to hypnotherapy, which is the practice of implanting suggestions on hypnosis . mother's subconscious, to support the conscious that controls the actions of mothers in undergoing labor (Mongan, 2007). According to Fathony's research (2017), there is a difference in the intensity of pain in the active phase I labor between active mothers with hypnobirthing method and without hypnobirthing method. 
Mothers who were not given the hypnobirthing method had 4.50 times the chance to experience severe pain compared to mothers with the hypnobirthing method. One of the roles of nurses is to provide professional nursing care to improve the quality of life of mothers in labor and make mothers feel safe and comfortable or able to adapt to the pain that is felt during intercourse. The phenomenon found at Achmad Mocthar Bukittinggi Hospital is that the pain scale assessment form has been attached to every patient who goes to RSAM, including patients who are about to give birth. Nonpharmacological methods used to reduce labor pain are only in the form of relaxation, massage and spiritual (getting closer to God), while the relaxation technique of hypnobirthing has never been done.

The initial survey was conducted on 5 mothers who were active in the first stage, 3 of them were unable to adapt to labor pain. This can be seen from the pain scale of the patient which is increasingly increasing, meaning that the patient is unable to adapt to the pain that occurs. The action taken by the officer to overcome the pain is to encourage the family to do massage and motivate the patient to get closer to God. The purpose of this study was to determine the effect of hypnobirthing pain management on the adaptation ability of maternal pain that spontaneously gives birth in the Maternity Action Room of Achmad Mocthar Hospital in Bukittinggi 2019.

\section{RESEARCH METHODS}

The research design is the design of a quasi-experimental design with treatment replications (pretest posttest with control group), the research design using only one group of subjects and take measurements before and after treatment of the subject. The sample used as many as 16 people.

The way to take samples is by using purposive sample technique, which is sampling based on certain considerations made by the researcher, based on the characteristics or characteristics of the population that have been known previously. The sample was divided into 2 groups, namely group 1 as many as 8 people were given management of hypnobirthing pain management, group 2 as many as 8 people were not given management of hypnobirthing pain management.

The mother who gave birth in the Achievement Test Room at Achmad Mocthar Bukittinggi Hospital in the active phase. Mother planned vaginal delivery. Induction / augmentation labor. Unplanned patients with SC. Can speak Indonesian well. Willing to be a respondent and cooperative

\section{Data Collection Methods}

Primary data collection is done through direct measurement of pain scale before intervention and after hypnobirthing pain management. Data collection was carried out after obtaining permission from the Hospital leadership then the researcher went to the Head of the Midwifery Room to carry out research and collaborate with nurses in the room to contact researchers if there were latent-active phase maternity mothers at stage I. After obtaining information from nurses in the room, then The researcher identifies the patient whether it meets the established inclusion and exclusion criteria. If the patient meets the criteria, the researcher submits the application letter to become a respondent, if the respondent agrees, then he is asked to sign an informed consent . Furthermore, data collection was conducted in accordance with the purpose of the study, namely observing the pain adaptation of respondents before and 
after hypnobirthing. After the pre-test pain scale, respondents were given Hypnobirthing for 10-15 minutes, after that the post-test pain scale was re-measured.

\section{RESULTS}

Table. 1

The mean change in Mother's Pain Adaptation Interventions Given Management Pain " Hipnobirthing"

\begin{tabular}{ccccccc}
\hline Pain Scale & The mean & $\begin{array}{c}\text { Elementary } \\
\text { school }\end{array}$ & SE & $\begin{array}{c}\text { Mean } \\
\text { Different }\end{array}$ & $\mathrm{T}$ & $\mathrm{p}_{\text {value }}$ \\
\hline Before & 5.12 & 0.835 & 0.295 & 1,000 & 3,742 & 0.007 \\
After & 4.12 & .641 & .227 & & \\
\hline
\end{tabular}

The analysis results obtained the average pain scale before the intervention was 5.12 (moderate pain), and after the intervention 4.12 (moderate pain). The mean of pain adaptation in mothers given hypnobirthing pain management intervention is 1 with pvalue $=0.007$, meaning that there is a difference in pain adaptation in mothers given hypnobirthing pain management intervention in the delivery room of the Achmad Mochtar Bukittinggi Hospital in 2019

Table. 2

The Mean Change Adaptation Pain in Mothers Not Provided Intervention Pain Management " Hipnobirthing "

\begin{tabular}{ccccccc}
\hline Pain Scale & $\begin{array}{c}\text { The } \\
\text { mean }\end{array}$ & $\begin{array}{c}\text { Elementary } \\
\text { school }\end{array}$ & SE & $\begin{array}{c}\text { Mean } \\
\text { Different }\end{array}$ & T & $\mathrm{p}_{\text {value }}$ \\
\hline Before & 5,38 & 0.744 & 0.263 & $-0,625$ & $-1,930$ & 0.095 \\
After & 6.00 & 0.756 & 0.267 & & & \\
\hline
\end{tabular}

The results of the analysis obtained the average pain scale before the control group was 5.38 (moderate pain), and 6.00 thereafter (moderate pain). The mean adaptation of pain in women who were not given pain management interventions hipnobirthing is -0.625 with $\mathrm{a}=$ 0.095 means there is no difference in pain adaptation in mothers who were not given pain management interventions hipnobirthing at $\mathrm{p}$ value room maternity hospital action Achmad Mochtar Bukittinggi in 2019.

Table. 3

The Effect of Hypnobirthing Pain Management on Adaptation Ability Maternal Pain that Spontaneous Delivery

\begin{tabular}{cccccc}
\hline Treatment group & $\mathrm{n}$ & $\begin{array}{c}\text { The } \\
\text { mean }\end{array}$ & $\begin{array}{c}\text { Elementary } \\
\text { school }\end{array}$ & $\begin{array}{c}\text { Mean } \\
\text { different }\end{array}$ & $p_{\text {value }}$ \\
\hline - Intervention & 8 & 1,00 & 0.756 & 1,625 & 0.002 \\
- control & 8 & -0.62 & 0.916 & & \\
\hline
\end{tabular}

Based on table 3 above, it is known that the average difference of pain adaptation between the intervention group and the control group is $1.625(1---0.62)$, with a value of $p=0.002 \quad(\mathrm{p}<0.05)$.It can be concluded that there is an influence of hypnobirthing pain management to the adaptation ability of maternal pain that gives birth spontaneously in the delivery room . 


\section{DISCUSSION}

\section{The Mean Change Adaptation Pain in Women Who Awarded Intervention Pain Management Hipnobirthing}

The analysis results obtained the average pain scale before the intervention was 5.12 (moderate pain), and after the intervention 4.12 (moderate pain). The mean of pain adaptation in mothers given hypnobirthing pain management interventions is 1 with pvalue $=0.007$, meaning that there are differences in pain adaptation in mothers who are given hypnobirthing pain management interventions in the delivery room. In line with the research Ginting (2012) on the adaptation of labor pain in the Clinic $\mathrm{Hj}$. Mariani, that in the active phase the average mother is at moderate pain intensity (4$6)$.

Hypnobirthing is one of the non-pharmochological pain management, which includes deep relaxation, slow breathing patterns and instructions on how to release endorphins from the body. Hypnobirthing means the process of giving birth with hypnosis, the mother is fully aware and enjoys the process of labor. This method is rooted in the science of hypnosis with a psychiatric approach that gives women the opportunity to focus, and relax, so hypnobirthing refers more to hypnotherapy, which is a practice of implanting suggestions on the subconscious of the mother, to support the conscious nature that controls the mother's actions in undergoing the mother's actions childbirth (Mongan, 2007).

According to the assumptions of researchers, mothers who are given pain management internvensi hipnobirthing able to adapt to labor pain caused by the mother can experience the birth process positive affirmations given to the mother. The existence of hypnobirthing makes the mother able to concentrate, focus and relax, so that the mother's pain response is also getting better and the mother can adapt to the pain felt.

Differences in the ability to adapt to pain can be influenced by maternal parity and husband support. Mothers who are primiparas and also do not get support from families experience lower adaptation than multipara mothers and get husband support, because mothers feel anxious in the face of childbirth and affect the pain response felt by the mother. In accordance with Afritayeni's research (2017) that primipara has a longer and more tiring labor process compared to multipara. This is because the cervix on primiparous clients require more energy to experience stretching due to the influence of greater intensity of contractions during the first stage of labor. The presence of the closest person will help ease the burden and anxiety when facing labor.

\section{The Mean Change Adaptation Pain in Women who are not Given Intervention Pain Management Hipnobreathing}

The results of the analysis obtained the average pain scale before the control group was 5.38 (moderate pain), and 6.00 thereafter (moderate pain). The mean adaptation of pain in women were not given pain management hipnobirthing is -0.625 with $\mathrm{p}$ value $=0.095$ means there is no difference in pain adaptation in mothers who were not given pain management interventions hipnobirthing in the delivery room. In line with Fathony's research (2017) on the Influence of hypnobirthing Against Pain Intensity in First Stage Active Labor at BPM Utami's Wife And Tutik Purwani, Sleman Regency. Based on these studies it is known that $60 \%$ of mothers who do not do hypnobirthing experience severe pain. Labor pain is a physiological condition, labor pain starts in labor in the first stage of the latent and active phases. The latent phase 
occurs opening up to $3 \mathrm{~cm}$, can last for 8 hours. Pain originates from uterine contractions and cervical dilatation, with increasing volume and frequency of uterine contractions, the pain felt will get stronger, peak pain occurs in the active phase, where the opening occurs from $3 \mathrm{~cm}$ to $10 \mathrm{~cm}$ and lasts for 6 hours. Pain that occurs can affect the mother's condition in the form of fatigue, fear, worry and stress. Stress can cause a weakening of uterine contractions and end in prolonged labor and can even cause death (Sarwono, 2011). The intensity of pain experienced by the mother will increase over time due to contractions, amplitude, frequency and duration which are increasingly increasing (Prawiroharjo, 2008).

According to the researchers' assumptions, the low change in mean pain adaptation in the control group was due to the absence of interventions to reduce the respondent's pain scale, in this case the respondent was only directed to take a deep breath, a mass of extents carried out by the family and also a suggestion to get closer to God . Respondents who are unable to adapt to labor pain are caused by the absence of family support that can help massage the mother's back, so that the pain felt by the mother also increases with the progress of labor. Besides that, mothers who are unable to adapt to labor pain are caused by primipara, so they do not have experience in labor and while mothers who are able to adapt to labor pain are caused by support from the family to do massage, so mothers feel a little comfortable and able to adapt with the pain. Where the presence of the closest person will help ease the burden and anxiety when facing labor (Afritayeni, 2017).

In mothers with high parity (8) who are unable to adapt to labor pain, due to the anxiety of the mother with the delivery process due to high risk factors such as age at risk (39 years) and parity at risk (8). The situation of mothers who have experienced anxiety since pregnancy will worsen the conditions of pain experienced by mothers (Puspita, 2013). Based on table 3, it is known that the average difference of pain adaptation between the intervention group and the control group was $1.625(1-(-0.62)$, with a value of $p=0.002$ ( $\mathrm{p}<0.05$ ). It can be concluded that there is an influence of pain management hypnobirthing on adaptability of pain a mother who gave birth to s ecara spontaneous delivery room. in line with the research Fathony (2017) on Influence Hypnobirthing Against intensity pain in childbirth Kala I Phase Active in BPM wife Utami And Tutik Purwani Sleman district. Based on these studies it is known that. There is a difference in intensity pain during childbirth in the first phase of active maternity with hypnobirthing method and mothers without hypnobirthing method .

Hypnobirthing is a natural relaxation method used to eliminate fear, panic, tension and various other pressures that haunt the mother in the delivery process so that the mother can tolerate the pain that is felt (Abidin, 2007). Kuswandi (2007) in Andriana (2007) states that relaxation of hypnobirthing is a new method that is specifically for pregnant women with deep relaxation, aiming to prepare for a smooth, comfortable normal birth process with minimum pain with delivery methods with hypnobirthing

In line with Nursalam's research (2008) Based on these studies it is known that the method of hypnobirthing relaxation is proven to increase pain tolerance and decrease anxiety responses in mothers in labor during the active phase.

According to the researchers' assumptions, the influence of hypnobirthing pain management on the adaptation of maternal pain in labor is due to the pain management so that the mother can feel calm and comfort in the process of giving birth, the mother will be more able to control her emotions and feelings, prevent excessive fatigue during labor. With the management of pain, the attention of the mother can be diverted so that 
the mother is not focused on the pain that is felt, and produces a better pain response. Anxiety that is felt by the mother is also reduced by the relaxation given

\section{CONCLUSION}

Non-pharmacological pain management with Hipnobirthing shown to affect the patient's ability to adapt to labor yeri evidenced by the reduction of the fiscal a pain before and after dilakkan Hipnobirthing $(\mathrm{p}=0.002)$

\section{SUGGESTION}

To nurses in maternity care to be able to apply this non-pharmacological pain management to help adapt the patient's pain so that the patient can give birth comfortably. For further researchers, they can examine the differences in the adaptation of maternal pain in childbirth who received Hypnobirthing education during the third trimester of pregnancy visit with those during labor only.

\section{REFERENCES}

Abidin, A. (2007). Melahirkan tanpa Rasa Sakit. Makalah disajikan dalam Talkshow Melahirkan tanpa Rasa Sakit dengan Metode Hypnobirthing, Hotel Arjuna, Bandung

Afritayeni, A. (2017). Hubungan Umur, Paritas dan Pendamping Persalinan dengan Intensitas Nyeri Persalinan Kala I. Journal Endurance 2(2), 178-185

Andriana, A., \& Evariny, E. (2007). Melahirkan Tanpa Rasa Sakit dengan Metode Hypnobirthing. Jakarta: Bhina Ilmu

Dinkes Sumbar. (2018). Profil Kesehatan Sumatera Barat Tahun 2017. Padang. Dinkes Sumbar

Ermalena, E. (2017). Indikator Kesehatan SDGs di Indonesia. Jakarta. Diskusi Panel Tujuan Pembangunan Indonesia

Fathony, Z. (2017). Pengaruh Hypnobirthing terhadap Intensitas Nyeri pada Persalinan Kala I Fase Aktif di BPM Istri Utami dan Tutik Purwani Kabupaten Sleman. Jurnal Ilmu Keperawatan dan Kebidanan, 8(2), 1-7

Fraser, F., \& Cooper, C. (2012). Buku Saku Praktek Klinik Kebidanan. Jakarta: EGC

Ginting, A. (2012). Adaptasi Nyeri Persalinan di Klinik Hj. Mariani. Fakultas Keperawatan, Universitas Sumatera Utara

Kemenkes RI. (2017). Profil Kesehatan Indonesia Tahun 2016. Jakarta. Kemenkes RI

Manuaba, M. (2014). Ilmu Kebidanan, Penyakit Kandungan dan KB untuk Pendidikan Bidan. Jakarta. EGC

Mongan, M., \& Marie, F. (2007). Hypnobirthing. Jakarta. PT Bhuana Ilmu Populer

Nursalam, N. (2008). Hypnobirthing Meningkatkan Toleransi Nyeri dan Menurunkan Kecemasan Ibu Inpartu Kala I Fase Aktif. Jurnal Ners, 3(1),54-60

Prawiroharjo, S. (2008). Ilmu kebidanan. Jakarta. Yayasan Bina Pustaka

Puspita, A. D. (2013). Analisis Faktor-faktor yang Mempengaruhi Nyeri Persalinan pada Ibu Kala I Fase Aktif di Puskesmas Mergangsan. Skripsi. Prodi D IV Kebidanan STIKes Aisyiyah Yogyakarta

RSAM Bukittinggi. 2018. Medical Record 2018

Sarwono, P. (2011). Ilmu Kandungan. Jakarta. Bina Pustaka Sarwono Prawirohardjo

Varneys, H. (2012). Buku Ajar Asuhan Kebidanan. Diterjemahkan oleh Laily Mahmudah. Jakarta: EGC 
WHO. (2015). Trends in Maternal Mortality 1990 to 2015. WHO, UNICEF, UNFPA, World Bank Group

Wildan, M. (2013). Pengaruh Teknik Relaksasi terhadap Adaptasi Nyeri Persalinan Ibu Bersalinkala I Fase Aktif di BPS Wilayah Puskesmas Patrang Kabupaten Jember Tahun 2012. Jurnal IKESMA, 9(1) 